\title{
MASALAH RAWAN DALAM HUBUNGAN INDUSTRIAL DAN KONSEP NEGARA KESEJAHTERAAN INDONESIA
}

\author{
Ahmad Hunaeni Zulkarnaen \\ Dosen Program Magister Ilmu Hukum dan Dosen Fakultas Hukum \\ Universitas Suryakancana \\ E-mail: ahmadhunaeniz@unsur.ac.id
}

\begin{abstract}
ABSTRAK
Sasaran pembangunan Indonesia berupaya mencapai stabilitas nasional, termasuk stabilitas di bidang ekonomi, pencapaian stabilitas di bidang ekonomi nasional, ditentukan oleh stabilitas di sektor produksi barang dan jasa, atau stabilitas di sektor produksi barang dan jasa merupakan faktor pendukung yang dominan untuk suksesnya program pembangunan nasional khususnya program pembangunan bidang ekonomi, dan salah satu syarat untuk mewujudkan stabilitas di sektor produksi barang dan jasa diperlukan kondisi hubungan industrial yang harmonis yang berdasarkan Pancasila berupa terciptanya ketenangan kerja dan berusaha atau industrial peace, adalah suatu kondisi yang dinamis di dalam hubungan kerja di perusahaan dimana terdapat 3 (tiga) unsur penting: pertama hak dan kewajiban terjamin dilaksanakan, kedua apabila timbul perselisihan dapat diselesaikan secara internal, ketiga mogok dan penutupan perusahaan (lock-out) tidak perlu digunakan untuk memaksakan kehendak, karena perselisihan yang terjadi telah dapat diselesaikan dengan baik. Pada kenyataannya untuk menciptakan suatu hubungan industrial yang harmonis adalah tidak mudah, ada beberapa yang menjadi faktor-faktor penyebabnya yaitu; faktor penyebab dari pihak pekerja/buruh, faktor penyebab dari pihak pengusaha dan faktor penyebab dari pihak aparat pemerintah.
\end{abstract}

Kata kunci: Masalah Rawan dalam Hubungan Industrial, Konsep Negara Kesejahteraan Indonesia.

\begin{abstract}
The Indonesian's Development goal is to achieve national stability, including economical stability, the achievement of nationally economical stability, determined by the stability in the sector of production of goods and services, or its stability in the sector of production of goods and services is the supporting factor to the dominant of national development programs especially economic development program. One of the requirements to achieve stability in the sectoral production of goods and services is the condition of harmonious industrial relations based on Pancasila in the form of peaceful in working situation or industrial peace, is a dynamic condition in working, where there 3 (three) important elements: first the guarantee implementation on rights and obligations; second, conflict can be resolved internally; third, strikes and lockouts (lock-out) should not be used to impose willingness, because conflict could have been resolved well. In fact, in creating a harmonious industrial relations is not easy, there are some contributing factors such as; workers / laborers factor, employers factor, and public administration factor.
\end{abstract}

Keywords: Industrial Relationship Problem, Indonesian Welfare State Concept 


\section{PENDAHULUAN}

Indonesia adalah sebagai Negara Hukum, hal ini sebagaimana dinyatakan dalam Pasal 1 ayat (3) Undang-Undang Dasar 1945 bahwa "Negara Indonesia adalah negara hukum". Selain sebagai negara hukum juga sebagai negara kesejahteraan (welfare state) sebagaimana tertuang dalam pembukaan Undang-Undang Dasar 1945 alinea ke 4 (empat) bahwa Negara Indonesia selain bertugas menyelenggarakan pemerintahan juga berkewajiban menyelenggarakan kesejahteraan umum.

Sebagaimana tugas menyelenggarakan kesejahteraan umum inilah, termasuk membenarkan negara turut campur dalam bidang kehidupan ketenagakerjaan. Status negara kesejahteraan telah menjadi ciri dari semua negara yang mengaku sebagai negara hukum yang sering disebut juga dengan istilah negara hukum modern, atau negara hukum dalam arti kata luas, yaitu tugas negara selain menyelenggarakan pemerintahannya juga berkewajiban menyelenggarakan kesejahteraan umum (welfare state). Identitas Indonesia sebagai negara kesejahteraan telah dinyatakan dalam pembukaan UndangUndang Dasar 1945, alinea 4 (empat) yang antara lain menyatakan kewajiban negara "memajukan kesejahteraan umum".

Selain sebagai negara kesejahteraan Indonesia juga sebagai negara hukum, maka semua alat perlengkapan dari negara, khususnya alat perlengkapan dari pemerintahan dalam tindakantindakannya baik tindakan alat perlengkapan pemerintahan terhadap rakyat, maupun tindakan antar alat perlengkapan pemerintahan tersebut harus sesuai dengan hukum yang berlaku, dan semua penduduk dalam perhubungan kemasyarakatan harus tunduk pada peraturan hukum yang berlaku. ${ }^{2}$ Identitas Indonesia sebagai negara hukum mempunyai pengertian negara Indonesia harus berdiri berdasarkan hukum, artinya semua tindakan para penguasa negara maupun rakyat diatur oleh hukum.

Konsekuensi Indonesia sebagai negara kesejahteraan, negara harus ikut campur dalam kehidupan rakyat, termasuk ikut campur dalam bidang ketenagakerjaan. Dampak campur tangan negara dalam bidang ketenagakerjaan membawa akibat terjadinya suatu pergeseran dalam hukum perburuhan atau hukum ketenagakerjaan,

2 Wiryono Projodikoro, Azas-azas IImu Negara, cetakan ke-2, 1981, hlm. 37. 
yaitu yang semula Hukum Perburuhan atau Hukum Ketenagakerjaan ini, hanya merupakan aspek hukum perdata, bergeser ke aspek hukum publik atau Hukum Administrasi Negara. ${ }^{3}$

Sesuai identitas Indonesia sebagai negara hukum maka semua peraturan ketenagakerjaan yang dikeluarkan oleh negara harus mengacu kepada UndangUndang Dasar 1945, antara lain pada Pasal 27 ayat (2), yang menyatakan "Setiap warga negara berhak atas pekerjaan dan penghidupan yang layak bagi kemanusiaan".

\section{PEMBAHASAN}

\section{A. SISTEM HUBUNGAN}

\section{INDUSTRIAL INDONESIA}

Menurut C.F.G. Sunaryati

Hartono sistem adalah "sesuatu yang terdiri dari sejumlah unsur atau komponen yang selalu pengaruh mempengaruhi dan terkait satu sama lain oleh satu atau beberapa asas". ${ }^{4}$ Menurut

Sudikno Mertokusumo, memberikan pengertian sistem adalah "kesatuan utuh dari tatanan-tatanan yang terdiri dari

3 Moh. Kusnadi H, Pengantar Hukum Tata Negara Indonesia, Pusat Syudy HTN Fak. Hukum UI, Depok, 1976, hIm. 5

4 C.F.G. Sunaryati Hartono, Politik Hukum Menuju Satu Sistem Hukum Nasional, Alumni, Bandung, 1991, hlm. 56. bagian-bagian yang satu sama lain berhubungan dan kait mengait secara erat untuk satu tujuan". ${ }^{5}$

Pengertian sistem hubungan industrial menurut Suwarto adalah: "Sistem hubungan yang terbentuk antara pelaku proses produksi barang dan/atau jasa". ${ }^{6}$ Di bawah ini akan diuraikan beberapa pengertian tentang Hubungan Industrial dari beberapa sarjana, diantaranya menurut Suprihanto:

"Hubungan yang membahas seluruh aspek dan permasalahan ekonomi, sosial, politik dan budaya baik yang secara langsung maupun tidak langsung yang berkaitan dengan hubungan pekerja/ buruh, pengusaha dan pemerintah". 7

Menurut Suwarto, memberikan dua pengertian dalam mendefinisikan hubungan industrial:

"Sistem hubungan yang terbentuk antara para pelaku proses produksi barang dan/atau jasa, dimana pihak buruh dan pihak pengusaha, adalah sebagai pihak yang secara fisik terlibat langsung, sedangkan pihak pemerintah terlibat di dalam hal-

5 Sudikno Mertokusumo dalam H.C. Chaerudin, Politik Hukum Indonesia, Fakultas Hukum UNSUR, 2003, hlm. 6.

6 Suwarto, Hubungan Industrial Dalam Praktik, Asosiasi Hubungan Industrial Indonesia, Jakarta, 2003, hlm. 1.

7 Sri Haryani, Hubungan Industrial di Indonesia, UPP AMP YKPN, Yogyakarta, 2002, hlm. 3. 
hal tertentu secara tidak langsung". 8

Sendjun memberikan H Manulang, pengertian tentang Hubungan Industrial, adalah:

"Hubungan industrial adalah sistem hubungan yang terbentuk antara pelaku dalam proses produksi barang dan/atau jasa (pekerja/ buruh, pengusaha dan pemerintah) yang didasarkan atas nilai-nilai yang merupakan manifestasi dari keseluruhan silasila dari Pancasila dan UndangUndang Dasar 1945 yang tumbuh dan berkembang diatas kepribadian bangsa dan kebudayaan nasional Indonesia". 9

H. Zainal Asikin, memberikan pengertian atau definisi tentang Hubungan Industrial, adalah:

"Hubungan Industrial, adalah sistem hubungan yang terbentuk antara para pelaku dalam proses produksi barang dan/atau jasa (pekerja/buruh, pengusaha, dan pemerintah) yang didasarkan atas nilai-nilai yang merupakan manifestasi dari keseluruhan silasila dari Pancasila dan UndangUndang Dasar 1945 yang tumbuh dan berkembang di atas kepribadian bangsa dan kebudayaan nasional Indonesia". ${ }^{10}$

Suwarto, Op.Cit. hlm 1.

9 Sendjun H. Manulang, Pokok-Pokok Hukum Ketenagakerjaan di Indonesia, Rineka Cipta, Jakarta, 1987, hlm. 145.

10 H. Zainal Asikin dkk., Dasar-Dasar Hukum Perburuhan, PT RadjaGrafindo Persada, Jakarta, 1993, hlm. 238.
Undang-undang Nomor 13 Tahun 2003 memberikan pengertian Hubungan Industrial, adalah:

"Suatu sistem hubungan yang terbentuk antara para pelaku dalam proses produksi barang dan/atau jasa yang terdiri dari unsur pengusaha, pekerja/buruh, dan pemerintah yang didasarkan pada nilai-nilai Pancasila dan UndangUndang dasar Negara Republik Indonesia Tahun 1954".

Hubungan Industrial adalah sistem hubungan yang terbentuk antara para pelaku dalam proses produksi barang dan/atau jasa, yang terdiri dari unsur pekerja/buruh, pengusaha, dan pemerintah, yang didasarkan kepada nilai-nilai dan hukum dasar suatu bangsa atau negara.

Menurut Abdul Khakim, dalam bukunya "Pengantar Hukum Ketenagakerjaan Indonesia Berdasarkan UndangUndang Nomor 13 Tahun 2003” memberikan pengertian hubungan industrial lebih berdasarkan kepada teori hubungan industrial Pancasila, yaitu:

"Suatu sistem yang terbentuk antara pelaku dalam proses produksi barang dan jasa (pekerja, pengusaha dan pemerintah) yang didasarkan kepada nilai-nilai Pancasila dan Undang-Undang Dasar 1945, yang tumbuh dan berkembang di atas kepribadian 
bangsa dan kebudayaan Nasional Indonesia". ${ }^{11}$

Pengertian hubungan industrial menurut Abdul Khakim ini sama dengan pengertian hubungan yang dirumuskan dalam Pasal 1 angka (16) Undang-Undang Nomor 13 Tahun 2003 tentang Ketenagakerjaan, yang memberikan pengertian pada hubungan industrial, adalah:

"Sistem hubungan yang terbentuk antara pelaku dalam suatu proses produksi barang dan/atau jasa yang terdiri dari unsur-unsur pengusaha, pekerja/buruh, dan pemerintah yang berdasarkan nilai-nilai Pancasila dan Undang-Undang Dasar Negara Republik Indonesia Tahun 1945".

Upaya menciptakan hubungan industrial yang selaras, serasi, dan harmonis, maka perlu dikembangkan keseimbangan antara kepentingan pekerja buruh, pengusaha, dan pemimpin, karena ketiga komponen tersebut mempunyai masing-masing kepentingan, yaitu: untuk pekerja/buruh perusahaan merupakan tempat untuk bekerja sekaligus sebagai sumber penghasilan dan penghidupan diri beserta keluarganya, untuk pengusaha

11 Abdul Khakim, Pengantar Hukum Ketenagakerjaan Indonesia, Berdasarkan Undang-Undang Nomor 13 Tahun 2003, PT. Citra Aditya Bakti, Bandung, 2003. hlm 49. perusahaan adalah wadah untuk mengeksploitasi modal guna mendapat keuntungan yang sebesar-besarnya dan untuk pemerintah perusahaan merupakan bagian dari kekuatan ekonomi yang menghasilkan barang atau jasa untuk memenuhi kebutuhan masyarakat. ${ }^{12}$

\section{B. RUANG LINGKUP HUBUNGAN INDUSTRIAL}

Berdasarkan paparan di atas, hubungan industrial adalah sistem hubungan yang terbentuk diantara para pihak dalam suatu proses produksi dan/atau jasa (pekerja/buruh, pengusaha, pemerintah) yang berlandaskan asas-asas atau nilai-nilai tertentu. Ruang lingkup hubungan industrial menurut Heidjrahman, adalah "bahwa hubungan industrial secara garis besarnya dibedakan menjadi dua, yaitu masalah man power marketing dan masalah man power management". ${ }^{13}$

Ruang lingkup hubungan industrial, baik yang menyangkut masalah man power marketing dan masalah man power management, pada hakekatnya akan selalu membahas syarat-syarat kerja dengan segala

12 H. Zainal Asikin dkk., Dasar-dasar Hukum Perburuhan,... Op Cit. hlm. 236.

13 Sri Haryani (ed), Hubungan Industrial di Indonesia,... Op Cit. hlm. 3-4. 
permasalahan dan pemecahannya. Istilah syarat-syarat kerja, terdiri dari istilahistilah "syarat" dan istilah "kerja", dan menurut Kamus Besar Bahasa Indonesia arti dari "syarat" adalah, "janji, tuntutan atau permintaan yang harus dipenuhi", sedangkan istilah "kerja" artinya adalah "sesuatu yang dilakukan untuk mencari nafkah". Sebagaimana untuk memahami lebih jauh tentang istilah syarat kerja kita dapat menganalisa pendapat dari Sri Haryani, mengenai ruang lingkup hubungan industrial. ${ }^{14}$

Berdasarkan paparan dari Sri Haryani di atas, ruang lingkup hubungan industrial, yang menyangkut man power marketing (pemasaran tenaga kerja), secara umum membahas penentuan syarat-syarat kerja yang akan diterapkan dalam pelaksanaan ikatan kerja yang ada. Proses ini setelah pekerja/buruh dinyatakan diterima oleh pihak perusahaan. Penentuan syaratsyarat kerja ini dapat dilaksanakan oleh pekerja/buruh secara individu maupun oleh wakil-wakil pekerja/buruh yang tergabung dalam organisasi pekerja/ organisasi buruh. ${ }^{15}$

Penentuan syarat-syarat kerja secara individu, hanya individu tersebut yang terikat dengan ketentuan syaratsyarat kerja, karena ketentuan hanya menyangkut pekerja/buruh secara individu (perorangan), maka dalam penetapannya juga hanya melibatkan pekerja/buruh yang bersangkutan dengan pihak pengusaha atau perusahaan, yang selanjutnya disebut Individual bargaining. ${ }^{16}$

Selain penentuan syarat-syarat kerja secara individu seperti di atas, penentuan syarat-syarat kerja juga dapat dikenakan secara kelompok, dalam hal ini, maka kelompok pekerja/buruh dalam penentuan syarat-syarat kerja bagi dirinya kepada wakilnya yaitu serikat pekerja/serikat buruh, penentuan syaratsyarat kerja ini disebut collective bargaining. Sebagai konsekuensinya, para pekerja/buruh tersebut harus menerima syarat-syarat kerja yang telah disepakati oleh pihak pengusaha atau perusahaan dengan wakil pekerja. ${ }^{17}$ Jenis-jenis syarat kerja yang dimaksud di atas, misalnya jam kerja, hari kerja, tempat kerja, upah, jaminan sosial, dan lain-lain. ${ }^{18}$

Sebagaimana yang dimaksud dengan man power management adalah membahas pelaksanaan syarat-syarat

18 Ibid. 
kerja dan berbagai permasalahan serta pemecahannya. Proses ini terjadi setelah pekerja/buruh bergabung dengan perusahaan. Pelaksanaan syarat-syarat kerja dengan berbagai permasalahannya dan pemecahannya dapat diterapkan kepada pekerja/buruh secara individual maupun kepada keseluruhan pekerja/ buruh melalui organisasi pekerja/ organisasi buruh. ${ }^{19}$

Praktiknya pelaksanaan dan pemecahannya diterapkan secara individu, dalam kasus seperti ini berarti menyangkut personal management, karena hanya menyangkut pekerja/buruh secara individu (perorangan), maka dalam penanganannya juga hanya melibatkan pekerja/buruh yang bersangkutan dengan pihak pengusaha atau perusahaan. ${ }^{20}$

Selain pelaksanaan syarat-syarat kerja, penanganan permasalahan dan pemecahannya secara individu seperti di atas, hal itu juga dapat dilakukan secara berkelompok, melalui organisasi pekerja/organisasi buruh. Dalam hal seperti ini, maka kelompok pekerja tersebut akan mewakilkan pelaksanaan syarat-syarat kerja, penanganan permasalahan dan pemecahannya yang

19 Ibid. hlm 4-5.

20 Ibid. hlm 5. mewakilkan kepada organisasi pekerja/ organisasi buruh (labor relation). Sebagai konsekuensinya, para pekerja/ buruh tersebut harus menerima pelaksanaan syarat-syarat kerja, dan pemecahan permasalahannya kepada serikat pekerja/ serikat buruh. ${ }^{21}$

Secara terperinci pelaksanaan syarat-syarat kerja, permasalahan yang dihadapi dan pemecahannya yang diwakilkan kepada serikat pekerja/ serikat buruh akan meliputi: Penarikan tenaga kerja, pengembangan tenaga kerja, kompensasi, Integrasi, dan pemeliharaan.

Indonesia menganut sistem hubungan industrial yang berdasarkan Pancasila, Hubungan industrial Pancasila, adalah sistem hubungan yang terbentuk antara para pelaku dalam proses produksi barang dan jasa (pekerja, pengusaha, pemerintah) yang didasarkan atas nilai-nilai yang merupakan manifestasi dari keseluruhan sila-sila dari Pancasila dan UUD 1945 yang tumbuh dan berkembang di atas kepribadian bangsa dan kebudayaan nasional Indonesia. ${ }^{22}$

Pengertian di atas jelas bahwa hubungan industrial Pancasila meng-

21 Ibid.

22 Sendjun. H. Manulang, Pokok-Pokok.... Op Cit, hlm 145. 
hendaki para pihak yang terlibat di dalamnya melakukan suatu tindakan apa pun harus sesuai dengan nilai Pancasila, atau jelasnya hubungan Industrial Pancasila adalah hubungan industrial yang dijiwai oleh kelima Pancasila berbunyi: ${ }^{24}$

1. Suatu hubungan perburuhan yang didasarkan atas asas Ketuhanan Yang Maha Esa;

2. Suatu hubungan perburuhan yang didasarkan kemanusiaan yang adil dan beradab;

3. Suatu hubungan perburuhan yang di dalamnya mengandung asas yang mendorong ke arah Persatuan Indonesia;

4. Suatu hubungan perburuhan yang didasarkan atas prinsip musyawarah untuk mencapai mufakat;

5. Suatu hubungan perburuhan yang mendorong ke arah terciptanya keadilan sosial bagi seluruh rakyat Indonesia. ${ }^{25}$

Nilai-nilai Pancasila akan dapat menciptakan suasana dan lingkungan kerja yang baik, menyenangkan, tentram dan tertib, nilai-nilai Pancasila dan UUD

24 EX Djumiadji, dan Wiwoho Soedjono, dalam H. Zainal Asikin dkk., Dasar-dasar Hukum Perburuhan, PT RajaGrafindo Persada, Tahun 2004. hlm. 239.

25 H. Zainal Asikin dkk., Dasar-Dasar Hukum ... Op Cit. hlm. 239.
1945 dapat mengendalikan perilaku setiap insan, yaitu menjadi insan-insan berbudi baik, tertib, saling harga menghargai, saling membantu, saling isi mengisi, serta menjauhkan diri dari sifatsifat mementingkan diri sendiri, meremehkan insan lain, dan menekan dan/atau hendak memeras sesama insan lainnya.

\section{KONDISI KERJA (WORKING CONDITION) SEBAGAI SYARAT TERCIPTANYA HUBUNGAN INDUSTRIAL YANG HARMONIS}

Kondisi kerja (working condition) sebagai salah satu syarat terwujudnya hubungan industrial Pancasila dan berdasarkan UUD 1945, meliputi norma kerja (labour legislation) dan syarat kerja (term of employment).

\section{Norma Kerja (Labour Legislation)}

Pengertian Norma Kerja (Labour Legislation) adalah pengaturan hak dan kewajiban bagi pekerja/buruh dan pengusaha atau pimpinan perusahaan yang tertuang dalam peraturan perundang-undangan, bersifat imperatif, sifat wajib dan serta bersifat makro minimal, artinya tanpa kecuali mengikat semua perusahaan tanpa mempertimbangkan tempat, ukuran, jenis usaha, 
sifat badan hukum, dan lain sebagainya dari perusahaan tersebut dengan standar minimal, artinya bahwa perusahaan dapat saja menerapkan standar yang lebih baik dari pada yang diatur di dalam peraturan perundang-undangan yang diatur secara internal perusahaan. ${ }^{26}$ Adapun jenis-jenis norma kerja tersebut, adalah: Upah Minimum Kota atau Kabupaten, BPJS Ketenagakerjaan, Keselamatan Kerja atau Sistem Manajemen Kesehatan dan Keselamatan Kerja, Upah Lembur, dan lain-lain.

\section{Syarat Kerja (Term of Employment)}

Syarat kerja (term of employment) yang sifatnya mikro kondisional adalah pengaturan hak dan kewajiban antara pekerja/buruh dan pengusaha yang belum diatur dalam peraturan perundang-undangan, standar yang diatur hanya berlaku bagi perusahaan secara individual sesuai dengan kondisi perusahaan yang bersangkutan. ${ }^{27}$ Mikro dalam arti, diatur hanya untuk perusahaan tertentu secara individual, kondisional dalam arti pengaturan disesuaikan dengan kondisi atau kemampuan perusahaan yang bersangkutan, sedangkan bentuk syarat kerja ini

26 Suwarto, Hubungan Industrial Dalam Praktik,... Op.Cit, hlm. 4.

27 Ibid, hlm. 5. adalah: perjanjian kerja, peraturan perusahaan, perjanjian kerja bersama. Jenis-jenis syarat kerja dimaksud, seperti: uang makan, transport, bonus pencapaian produksi, perumahan, koperasi, pekerja/buruh diberi kesempatan untuk memiliki saham perusahaan, koperasi pekerja, rekreasi, dan lain-lain. Syarat terciptanya suatu hubungan industrial yang berdasarkan nilai-nilai Pancasila dan UUD 1945 yaitu teraplikasinya norma kerja (labour legislation) dan syarat kerja (term of employment) dalam suatu hubungan kerja dalam suatu perusahaan.

\section{NEGARA KESEJAHTERAAN DAN HUBUNGAN INDUSTRIAL INDONESIA}

Perundangan hubungan industrial dibuat pada hakekatnya selain bertujuan untuk memberikan perlindungan hukum kepada pekerja/ buruh, juga untuk mewujudkan kesejahteraan bagi seluruh rakyat Indonesia, dalam hal ini untuk mewujudkan kesejahteraan pengusaha, kesejahteraan pekerja/buruh dan kesejahteraan masyarakat. Sasaran akhir dari sistem hukum hubungan industrial adalah membuka atau memperluas lapangan kerja, mempertahankan, meningkatkan keberlangsungan 
pekerjaan dan mempertahankan, meningkatkan pendapatan yang sudah ada, atau dalam jangka panjang bertujuan untuk meningkatkan pendapatan perkapita masyarakat Indonesia. Sejalan dengan itu Koko Kosidin (almarhum) yang menyatakan, bahwa:

"Indonesia adalah suatu Negara Hukum dalam arti luas (negara kesejahteraan) yang sangat memperhatikan perlindungan hukum bagi setiap warga negaranya, dan sebagai negara kesejahteraan, Indonesia juga sangat memperhatikan upaya-upaya ke arah terciptanya kesejahteraan rakyatnya". ${ }^{28}$

Sejalan dengan pendapat Koko Kosidin (almarhum), SF Marbun, dkk mengatakan bahwa "tugas negara hukum pada abad modern ini, menyelenggarakan kepentingan umum dan kesejahteraan rakyat secara langsung". ${ }^{29}$ Cara negara mewujudkan kesejahteraan rakyatnya, yaitu dengan menyusun dan melaksanakan program pembangunan nasional, termasuk negara menyusun dan melaksanakan program pembangunan di bidang ekonomi. Pengertian pembangunan ekonomi disini

28 Koko Kosidin, Aspek-aspek Hukum dalam Pemutusan Hubungan Kerja di Lingkungan Perusahaan (Persero), Disertasi UNPAD, Bandung, 1996, hlm. 13.

29 SF. Marbun dkk. (Pen) Dimensi-Dimensi Pemikiran Hukum Administrasi Negara, Uli Press, Yogyakarta, hlm 64-65. menurut Meier dan Baldwin dalam bukunya "Economics Development, Theory, History and Policy":

"Economic development is a process whereby an economy's real national income increase on a long period of time. And if the rate of development is greater than rate of population growth, then per capita real income will increase". ${ }^{30}$

Pembangunan ekonomi diartikan sebagai "suatu proses yang menyebabkan pendapatan perkapita penduduk suatu masyarakat meningkat dalam jangka panjang”.

Pengertian pembangunan ekonomi tersebut mengandung tiga unsur.

1. Pembangunan ekonomi;

2. Usaha meningkatkan pendapatan perkapita.

3. Kenaikan pendapatan perkapita harus berlangsung dalam jangka panjang. ${ }^{31}$

Tujuan akhir dari sistem hubungan industrial sangat mendukung terhadap pencapaian dari tujuan ekonomi nasional, tujuan sistem hubungan industrial adalah "kesejahteraan bagi semua pihak", yaitu untuk pihak pengusaha berupa peningkatan

30 Suryana, "Ekonomi Pembangunan Problematika dan Pendekatan" Penerbit Salemba Empat, Jakarta. Tahun 2000. hlm. 3. 31 Ibid. 
produktivitas dan bagi pekerja/buruh berupa peningkatan kesejahteraan, dan peningkatan ini harus dilakukan dari waktu kewaktu. ${ }^{32}$ Hal ini sejalan dengan pendapat dari beberapa sarjana tentang pengertian dari sistem hubungan industrial, seperti pengertian Hubungan Industrial dari Suprihanto yang menyatakan bahwa: "Hubungan yang membahas seluruh aspek dan permasalahan ekonomi, sosial, politik dan budaya baik yang secara langsung maupun tidak langsung yang berkaitan dengan hubungan pekerja, pengusaha dan pemerintah". 33

Pengertian hubungan industrial menurut Suwarto, adalah:

"Suatu sistem hubungan yang terbentuk antara para pelaku dalam proses produksi barang dan/atau jasa yang terdiri dari unsur-unsur perusahaan, pekerja/buruh, dan pemerintah yang didasarkan pada nilai-nilai Pancasila dan UndangUndang Dasar Negara Republik Indonesia tahun 1945".34

Kalau dikaitkan antara pengertian dan tujuan dari sistem hubungan industrial dengan tujuan pembangunan ekonomi nasional, kurang lebih sebagai

32 Suwarto,... Op Cit, hlm. 14.

33 Sri Haryani, Hubungan Industrial di Indonesia, Op.Cit, hlm 3.

34 Suwarto, Undang-undang Naker Indonesia, ILO/ USA Declaration Project, Departemen Ketenagakerjaan dan Transmigrasi Indonesia, Jakarta, tahun 2003, hlm. 12. berikut: bahwa semua pihak yang terlibat langsung atau tidak langsung dalam sistem hubungan industrial, baik itu pekerja/buruh, pengusaha maupun pemerintah, berkewajiban bekerjasama satu dengan yang lainnya dengan melaksanakan fungsi dan tugasnya masing-masing secara sebaik-baiknya, untuk berupaya meningkatkan produktivitas perusahaan dan kesejahteraan pekerja/buruh, demi mewujudkan tujuan pembangunan ekonomi nasional (pertumbuhan dan pemerataan), dalam rangka mencapai tujuan negara sebagaimana tertuang dalam pembukaan Undang-Undang Dasar 1945, alinea 4 (empat), yaitu mencapai kesejahteraan umum.

Pihak-pihak yang terlibat dalam sistem hubungan industrial, mempunyai posisi dan fungsi yang berbeda-beda, yaitu ada pihak yang secara fisik terlibat langsung dan juga ada pihak yang secara tidak langsung terlibat.

Kewajiban utama pemerintah dalam sistem hubungan industrial, adalah mengadakan pengaturan tentang sistem hubungan industrial. Pengaturan ini dimaksudkan agar pelaksanaan hubungan industrial diantara pekerja/ buruh dan pengusaha bisa berjalan serasi dan seimbang, adil (harmonis). Fungsi 
pemerintah yang lainnya sebagai penegak hukum, dan penengah yang adil dalam menyelesaikan perselisihan antara pengusaha dengan pekerja/buruh demi menjaga kelangsungan dari suatu proses produksi dan kepentingan yang lebih luas, yaitu kelangsungan dan keberlanjutan program pembangunan ekonomi nasional.

Korelasi antara sistem hubungan industrial dengan tujuan pembangunan ekonomi, sama-sama ingin mewujudkan tujuan negara sebagaimana tertuang dalam pembukaan Undang-Undang Dasar 1945, artinya tujuan dari sistem hubungan industrial (produktivitas dan kesejahteraan pekerja/buruh) adalah sejalan dengan tujuan pembangunan ekonomi nasional (pertumbuhan dan pemerataan), yaitu tujuan produktivitas dalam sistem hubungan industrial adalah identik dengan tujuan pertumbuhan dalam pembangunan ekonomi nasional. Tujuan kesejahteraan pekerja/buruh dalam sistem hubungan industrial, adalah identik dengan tujuan peningkatan pendapatan per kapita atau pemerataan pada pembangunan ekonomi nasional.

Seperti telah dijelaskan di atas, karena Indonesia sebagai negara kesejahteraan, tugas negara menyejahterakan rakyat Indonesia, karena tugasnya ini pemerintah atau negara berwenang untuk ikut campur dalam pengaturan dan pelaksanaan hubungan industrial di Indonesia. Maksud dari campur tangan pemerintah ini, adalah supaya pelaksanaan hubungan antara pekerja/buruh dengan pengusaha dapat berjalan secara serasi, seimbang dan adil (harmonis), tetapi karena Indonesia selain sebagai negara kesejahteraan, juga sebagai negara hukum, maka campur tangan pemerintah dalam hubungan industrial tersebut, harus didasarkan kepada peraturan undang-undang yang berlaku. ${ }^{35}$

\section{E. DASAR HUKUM HUBUNGAN INDUSTRIAL}

Salah satu payung hukum yang mengatur tentang sistem hubungan industrial di Indonesia, adalah UndangUndang Nomor 13 Tahun 2003 tentang Ketenagakerjaan, yang mana khusus untuk sistem hubungan industrial diatur dalam Pasal 102 dan Pasal 103.

Peraturan perundangan tentang pelaksanaan dari sistem hubungan industrial, tersebar diberbagai peraturan perundangan, baik peraturan perundangan setingkat undang-undang,

35 SF. Marbun (Pen),... Op Cit, hlm. 12. 
atau peraturan perundangan yang dikeluarkan oleh pemerintah (Presiden, Menteri). Peraturan perundangan tersebut lebih banyak mengatur mengenai hal-hal yang berkaitan dengan saranasarana dan kondisi kerja (labour condition) hubungan industrial, peraturan perundangan tersebut misalnya mengatur tentang: kebebasan berserikat dan perlindungan hak untuk berorganisasi, peraturan perusahaan dan perundingan pembuatan perjanjian perburuhan, pelaksanaan tata cara pembuatan kesepakatan kerja bersama, petunjuk penyelesaian perselisihan hubungan industrial dan pemutusan hubungan kerja di tingkat perusahaan dan pemerataan dan lain-lain.

Tujuan lain dari peraturan sistem hubungan industrial, adalah untuk menciptakan hubungan industrial harmonis, mewujudkan ketenangan baik dalam bekerja, maupun ketenangan dalam berusaha, dapat mencegah dan menanggulangi perselisihan hubungan industrial.

Pengertiannya "perselisihan hubungan industrial" menurut Dewan Pimpinan Pusat Ikatan Perantaraan Hubungan Industrial Indonesia, ialah:

"Perbedaan pendapat yang mengakibatkan pertentangan antara pengusaha atau gabungan pengusaha dengan pekerja/ buruh atau serikat pekerja/ serikat buruh karena adanya perselisihan mengenai hak, perselisihan kepentingan, perselisihan pemutusan hubungan kerja dan perselisihan antara serikat pekerja/ serikat buruh dalam satu perusahaan". ${ }^{36}$

Pengertian perselisihan hubungan industrial seperti yang telah dipaparkan di atas sama dengan pengertian perselisihan hubungan industrial yang diatur dalam Undang-Undang Nomor 2 Tahun 2004 tentang Penyelesaian Perselisihan Hubungan Industrial, ialah perbedaan pendapat yang mengakibatkan pertentangan antara pengusaha atau gabungan pengusaha dengan pekerja/ buruh atau serikat pekerja/serikat buruh, karena ada perselisihan mengenai hak, perselisihan kepentingan, perselisihan mengenai pemutusan hubungan kerja dan perselisihan antar serikat pekerja/ serikat buruh dalam satu perusahaan.

\section{F. MASALAH RAWAN DALAM HUBUNGAN INDUSTRIAL}

Telah dipaparkan di atas, sasaran pembangunan Indonesia berupaya mencapai stabilitas nasional, termasuk stabilitas di bidang ekonomi. Pencapaian stabilitas di bidang ekonomi nasional,

36 Muzni Tambusai, Penyelesaian Perselisihan Hubungan Industrial di Indonesia, DPP IPHII, Jakarta 2004, hlm. 11. 
ditentukan oleh stabilitas di sektor produksi barang dan jasa, atau stabilitas di sektor produksi barang dan jasa merupakan faktor pendukung yang dominan untuk suksesnya program pembangunan nasional khususnya program pembangunan bidang ekonomi, dan salah satu syarat untuk mewujudkan stabilitas di sektor produksi barang dan jasa diperlukan kondisi hubungan industrial yang harmonis yang berdasarkan Pancasila.

Pada kenyataannya untuk menciptakan suatu hubungan industrial yang harmonis yang berdasarkan Pancasila adalah tidak mudah, beberapa faktor penyebabnya yaitu; penyebab dari pekerja/buruh, penyebab dari pengusaha dan penyebab pihak aparat pemerintah ${ }^{37}$ dan penyebab dari peraturan perundangundangan (hukum acara) dalam penyelesaian perselisihan hubungan industrial.

\section{Dari Buruh/Pekerja}

a. Tingkat pendidikan yang relatif rendah sehingga mudah dipengaruhi tanpa adanya alasan yang rasional;

b. Bagi pekerja yang berpendidikan relatif tinggi, misalnya SLTA merasa tidak memiliki masa depan yang baik, terbukti setelah bekerja dalam waktu yang cukup lama kondisinya tidak mengalami kemajuan yang berarti, bahkan jenis pekerjaan yang dilakukan sering tidak memerlukan tingkat pendidikan tersebut;

c. Adanya semangat kebersamaan/ solidaritas pekerja/buruh yang tinggi karena merasa mempunyai nasib yang sama;

d. Adanya perasaan kesenjangan sosial-ekonomi yang cukup tinggi antara tingkat pimpinan dan pekerja/buruh pada umumnya di perusahaan;

e. Peningkatan kebutuhan pekerja/ buruh sebagai akibat kemajuan dan tuntutan konsumsi masyarakat pada umumnya;

f. Semakin tingginya kesadaran pekerja/buruh dalam menuntut hak mereka, bahkan tuntutan juga terjadi terhadap berbagai fasilitas kesejahteraan yang sebenarnya belum menjadi hak mereka;

g. Pengaruh internasional yang mengangkat masalah hak asasi manusia yang menjadi bagian kebebasan berserikat serta semangat demokrasisasi. ${ }^{38}$ 


\section{Dari Pengusaha}

a. Berbagai hak normatif pekerja/ buruh tidak diberikan oleh pengusaha, sehingga memicu ketidakpuasan;

b. Masih banyak pengusaha yang tidak memahami secara peraturan perundang-undangan, sehingga juga tidak diterapkan secara baik;

c. Program kesejahteraan pekerja/ buruh oleh sementara pengusaha dianggap sebagai beban biaya;

d. Memperlakukan pekerja/buruh sebagai alat produksi semata, dan kurang menghargai bahwa mereka sebagai manusia dengan segala harkat dan martabatnya. ${ }^{39}$

\section{Dari Pemerintah}

a. Sering tidak dapat melakukan tugas secara objektif, dan bahkan dalam menyelesaikan masalah sering memihak;

b. Kurangnya pemahaman secara mendalam terhadap berbagai peraturan perundang-undangan, terutama pemahaman terhadap latar belakang filosofi diterbitkannya peraturan perundang-undangan yang bersangkutan; c. Kurang kemampuan menjelaskan berbagai prinsip hubungan industrial pada umumnya dan peraturan perundang-undangan ketenagakerjaan pada khususnya;

d. Lemahnya dan tidak konsistennya penegakan hukum. ${ }^{40}$

\section{Dari Peraturan Perundang-}

\section{Undangan Tentang Penyelesaian}

\section{Perselisihan Hubungan Industrial}

Kenyataannya sistem penegakan hukum dan pelaksanaan hukum hubungan industrial di Indonesia masih jauh dari harapan, salah satu kelemahannya adalah selain pada aspek penerapan atau penegakannya juga pada peraturan perundang-undangan yang mengatur sistem hubungan industrial, yaitu beberapa peraturan perundang-undangan yang mengatur tentang penyelesaian perselisihan hubungan industrial belum sesuai cita negara hukum Pancasila, yaitu hukum acara yang dipergunakan oleh Undang-Undang Nomor 2 Tahun 2004 tentang Penyelesaian Perselisihan Hubungan Industrial adalah Reglemen Indonesia yang diperbaharui (Het herzeine Indonesisch Reglement (HIR) Staatsblad 1941-44, Reglemen Acara untuk luar Jawa dan Madura (Rechtsreglement Buitenngewesten

40 Ibid. 
(Rbg), Staatsblad 1927: 227, dan Reglement op de bergerlijke Rechtsvordering $(R v)$ terdapat dalam Staatsblad. 1847-52 juncto Staatsblad. 1849-63. $R v$ adalah Kitab UndangUndang Hukum Acara Perdata yang berlaku untuk orang Belanda, sedangkan Kitab Undang-Undang Hukum Acara Perdata yang berlaku untuk orang Indonesia adalah HIR (untuk Jawa dan Madura) dan Rbg (untuk luar Jawa dan Madura). ${ }^{41}$

$H I R, \quad R b g$ dan $R v$ adalah sistem hukum acara perdata warisan kolonial Belanda dengan paradigma sistem hukum Eropa Kontinental yang menganut falsafah individualism dengan pola demokrasi liberal, ciri-ciri falsafah individualisme dan demokrasi liberal adalah: mengakui adanya perbedaan kepentingan, kebebasan individu menduduki tempat yang tertinggi, penyelesaian setiap perbedaan dilakukan dengan cara adu kekuatan termasuk dalam penyelesaian perselisihan hubungan industrial. Konsep kebebasan liberalisme di bidang ekonomi menimbulkan kapitalisme, yaitu suatu konsep yang memberikan kebebasan kepada anggota masyarakat untuk

41 Munir Fuady, Arbitrase Nasional, Alternatif Penyelesaian Sengketa Bisnis, PT Citra Aditya Bakti, Bandung, Tahun 2003, hlm. 27-28. berusaha dan bersaing dengan sedikit sekali campur tangan pemerintah, sehingga dalam praktiknya seringkali terjadi yang kuat (pengusaha) menekan yang lemah (pekerja/buruh). Tujuan hukum menurut konsep liberalisme adalah melindungi kebebasan individuindividu dalam masyarakat, berdasarkan paparan di atas tujuan hukum berdasarkan faham liberalisme tidak sesuai dengan teori pengayoman dari tujuan hukum yang dianut oleh sistem hukum hubungan industrial Indonesia yang berdasarkan Pancasila, teori pengayoman mengajarkan yang kuat (pihak pengusaha) harus melindungi yang lemah (pihak pekerja/buruh).

\section{PENUTUP}

Peraturan perundangan-undangan hubungan industrial dibuat pada hakekatnya selain bertujuan untuk memberikan perlindungan hukum kepada pekerja/buruh, juga untuk mewujudkan kesejahteraan bagi seluruh rakyat Indonesia, dalam hal ini untuk mewujudkan kesejahteraan pengusaha, kesejahteraan pekerja/buruh dan kesejahteraan masyarakat. Sasaran akhir dari sistem hukum hubungan industrial Indonesia adalah membuka atau memperluas lapangan kerja, memper- 
tahankan, meningkatkan keberlangsungan pekerjaan dan mempertahankan, meningkatkan pendapatan yang sudah ada, atau dalam jangka panjang bertujuan untuk meningkatkan pendapatan perkapita masyarakat Indonesia

Semua pihak yang terlibat dalam sistem hubungan industrial, baik itu pekerja/buruh, pengusaha maupun pemerintah, berkewajiban bekerjasama satu dengan yang lainnya dengan melaksanakan fungsi dan tugasnya masing-masing secara sebaik-baiknya dalam upaya meningkatkan produktivitas perusahaan dan kesejahteraan pekerja/ buruh, demi mewujudkan tujuan pembangunan ekonomi nasional (pertumbuhan dan pemerataan), dalam rangka mencapai tujuan negara kesejahteraan Indonesia sebagaimana tertuang dalam pembukaan Undangundang dasar 1945, alinea 4 (empat), yaitu mencapai kesejahteraan umum, untuk itu Indonesia menganut sistem hubungan industrial yang berdasarkan Pancasila, suatu sistem hubungan yang terbentuk antara para pelaku dalam proses produksi barang dan jasa (pekerja, pengusaha, pemerintah) yang didasarkan atas nilai-nilai yang merupakan manifestasi dari keseluruhan sila-sila dari Pancasila dan UUD 1945 yang tumbuh dan berkembang di atas kepribadian bangsa dan kebudayaan nasional Indonesia.

Berdasarkan paparan di atas para pihak yang terlibat di dalam hubungan industrial dalam melakukan suatu tindakan apa pun harus sesuai dengan lima nilai Pancasila, yaitu mengakui dan meyakini kerja sebagai pengabdian manusia kepada Tuhan dan sesama manusia, tidak menganggap buruh sebagai faktor produksi tetapi sebagai manusia pribadi dengan segala harkat dan martabatnya, suatu hubungan yang di dalamnya mengandung asas yang mendorong ke arah persatuan Indonesia, tidak membedakan golongan, perbedaan keyakinan, politik, paham, aliran, suku, agama maupun kelamin, suatu hubungan yang didasarkan atas prinsip musyawarah untuk mencapai mufakat, berusaha menghilangkan perbedaan dan mencari persamaan-persamaan ke arah persatuan antara buruh dan pengusaha, suatu hubungan yang mendorong ke arah terciptanya keadilan sosial bagi seluruh rakyat Indonesia. Atau menurut Suwarto hubungan industrial yang harmonis atau industrial peace, adalah suatu kondisi yang dinamis di dalam hubungan kerja di perusahaan dimana terdapat 3 (tiga) unsur penting: pertama hak dan 
kewajiban terjamin dilaksanakan, kedua apabila timbul perselisihan dapat diselesaikan secara internal, ketiga mogok dan penutupan perusahaan (lockout) tidak perlu digunakan untuk memaksakan kehendak, karena perselisihan yang terjadi telah dapat diselesaikan dengan baik

Pada kenyataannya untuk menciptakan suatu hubungan industrial yang harmonis atau industrial peace yang dijiwai oleh lima nilai Pancasila adalah tidak mudah, sumber masalah rawan dalam hubungan industrial yang harmonis atau industrial peace yang berdasarkan Pancasila adalah dapat berasal dari pekerja/buruh, dapat berasal dari pengusaha, dapat berasal dari aparat pemerintah dan dapat berasal dari peraturan perundang-undangan tentang hukum acara penyelesaian perselisihan hubungan industrial yang diatur dalam Undang-Undang Nomor 2 Tahun 2004 tentang Penyelesaian Perselisihan Hubungan Industrial adalah Reglemen Indonesia yang diperbaharui (Het herzeine Indonesisch Reglement (HIR), Reglemen Acara untuk luar Jawa dan Madura

(Rechtsreglement Buitenngewesten (Rbg), dan Reglement op de bergerlijke Rechtsvordering $(R v)$ sistem hukum acara perdata warisan kolonial Belanda dengan paradigma sistem hukum Eropa Kontinental yang menganut falsafah individualisme dengan pola demokrasi liberal yang tidak sesuai. 


\section{DAFTAR PUSTAKA}

\section{A. Buku}

Abdul Khakim, Pengantar Hukum Ketenagakerjaan Indonesia, Berdasarkan Undang-Undang Nomor 13 Tahun 2003, PT. Citra Aditya Bakti Bandung, 2003.

C.F.G. Sunaryati Hartono Politik Hukum Menuju Satu Sistem Hukum Nasional, Alumni, Bandung, 1991.

H. Zainal Asikin dkk, Dasar-Dasar Hukum Perburuhan, PT Radjagrafindo Persada, Jakarta 1993.

, Dasar-Dasar Hukum Perburuhan, PT RajaGrafindo Persada, 2004.

Moh. KusnadiH, Pengantar Hukum Tata Negara Indonesia, Pusat Studi HTN Fak. Hukum UI, 1976.

Munir Fuady, Arbitrase Nasional, Alternatif Penyelesaian Sengketa Bisnis, PT Citra Aditya Bakti, Bandung, 2003.

Muzni Tambusai, Penyelesaian Perselisihan Hubungan Industrial di Indonesia, DPP IPHII, Jakarta, 2004.

Sendjun H. Manulang, Pokok-Pokok Hukum Ketenagakerjaan di Indonesia, Rineka Cipta, Jakarta, 1987.

SF. Marbun dkk (Pen), Dimensi-Dimensi Pemikiran Hukum Administrasi Negara, Uli Press, Yogyakarta.
Sri Haryani, Hubungan Industrial di Indonesia, UPP AMP YKPN, Yogyakarta, 2002.

Suryana, Ekonomi Pembangunan Problematika dan Pendekatan, Salemba Empat, Jakarta, 2000.

Suwarto Hubungan Industrial Dalam Praktik, Asosiasi Hubungan Industrial Indonesia, Jakarta, 2003.

Undang-Undang Naker Indonesia, ILO / USA Declaration Project, Departemen Ketenagakerjaan dan Transmigrasi Indonesia, Jakarta, tahun 2003.

Wiryono Projodikoro Azas-azas Ilmu Negara, cetakan ke-2, Jakarta, 1998.

\section{B. Peraturan Perundang-undangan}

Undang-Undang Dasar 1945.

Undang-Undang Nomor 13 Tahun 2003 tentang Ketenagakerjaan.

Undang-Undang Nomor 2 Tahun 2004 tentang Penyelesaian Perselisihan Hubungan Industrial.

\section{Jurnal, Artikel, Makalah, Majalah, Koran, Internet, dan Lain-lain.}

Koko Kosidin, Aspek-aspek Hukum dalam Pemutusan Hubungan Kerja di Lingkungan Perusahaan 
(Persero), Disertasi UNPAD, H.C. Chaerudin, Politik Hukum Bandung, 1996.

Indonesia, Diktat, Fakultas Hukum UNSUR, 2003 